\title{
Carcinoma of the stomach
}

\section{By P. Correa, Louisiana State University Medical Center, rgor Perdido Street, New Orleans, Louisiana, USA}

Diet is generally accepted as the main factor in gastric cancer etiology. There is, however, no general agreement on the specific components of the diet supposedly responsible for gastric cancer. The geographic distribution of the disease shows marked inter-country contrasts but there are many examples of culturally-divergent populations inhabiting the same land but having contrasting gastric cancer rates. Migrants from high-risk areas acquire the low rates of adoptive countries. Culture, not race or geography, appears as the main determinant of gastric-cancer risk. Diet is the cultural component which offers the most logical explanation of inter-population contrasts. The 'gastric-cancer diet' has been characterized as follows: (a) low in animal fat and animal proteins; (b) high in complex carbohydrates; (c) a substantial proportion of the protein obtained from vegetable sources, mostly grains and tubercles; (d) low in salads and fresh, green, leafy vegetables; (e) low in fresh fruits, especially citrus; (f) high in salt. In addition, a controversial role of nitrates has been reported.

Items $a-c$ are prevalent in many populations at low risk. Items $d$ and e show inter-population consistency but the specific 'protective' ingredients in them remain to be determined. Excessive salt intake as a factor has epidemiologic and experimental support. The role of nitrate is related to the hypothesis of intragastric synthesis of nitroso-compounds, for which the relevant factor seems to be intra-gastric nitrite, not oral nor dietary nitrate nor nitrite.

Diet plays a prominent role in all steps of the etiologic model presently being discussed for gastric carcinogenesis.

\section{BIBLIOGRAPHY}

Bjelke, E. (1974). Scandinavian fournal of Gastroenterology 9 (Supplement 31 ) 164-1 79.

Correa, P. (1983). Cancer Surveys 2, 437-450.

Correa, P., Cuello, C., Fajardo, L. F., Haenszel, W., Bolaños, O. \& De Ramirez, B. (1983). fournal of the National Cancer Institute 70, 673-678.

Correa, P., Haenszel, W., Cuello, C., Archer, M. \& Tannenbaum, S. R. (1975). Lancet ii, 58-60.

Graham, S., Schotz, W. \& Martino, P., (1972). Cancer 30, 927-938.

Haenszel, W. \& Correa, P. (1975). Cancer Research 35, 3452-3459.

Haenszel, W., Kurihara, M., Locke, F. B., Shimuzu, K. \& Segi, M. (1976). Journal of the National Cancer Institute 56, 265-274.

Haenszel, W., Kurihara, M., Segi, M. \& Lee, E. K. C. (1972). Fournal of the National Cancer Institute 49, $969-988$.

Hirayama, T. (1963). Bulletin of the Institute of Public Health 12, 85-96.

Hirayama, T. (1968). Gann Monograph 3, $5^{-27}$. 
Hirayama, T. (1981). In Gastrointestinal Cancer: Endogenous Factors, Banbury Report no. 7, pp. 409-429 [W. R. Bruce, P. Correa, M. Lipkin, S. R. Tannenbaum and T. C. Wilkins, editors]. New York: Cold Spring Harbor Laboratories.

Joossens, J. V. (1980). In Epidemiology of Arterial Blood Pressure, pp. 489-508 [H. Kesteloot and J. V. Joossens, editors]. The Hague, Boston: Martinus Nijhoff Publishers.

Joossens, J. V. \& Geboers, J. (1981). Nutrition and Cancer 2, 250-26I.

Kawasaki, H., Morishige, F., Tanaka, H. \& Kimoto, E. (1982). Cancer Letters 16, 57-63.

Langhans, P., Heger, R. A., Hoberstein, J. \& Bunte H. (I981). Hepato-Gastroenterology 28, 34-37.

MacDonald, W. E., Anderson, F. H. \& Hashimoto, S. (1967). Canadian Medical Association fournal 96, $1521-1525$.

Nagai, M., Hashimoto, T., Yanagawa, H., Yokoyama, H. \& Minowa, M. (I982). Nutrition and Cancer $3,257^{-268}$.

Paymaster, J. C., Sanghvi, L. D. \& Gangadharan, P. (1968). Cancer 21, 279-288.

Piacek-Llanes, B. \& Tannenbaum, S. R. (1982). Carcinogenesis $3,1379^{-1} 3^{84}$.

Ruddell, W. S. J., Bone, E. S., Hill, M. J. \& Walters, C. J. (1978). Lancet i, 521-523.

Schirai, T., Imaida, K., Fukushima, S., Hasegawa, R., Tatematsu, M. \& Ito, N. (1982). Carcinogenesis 12, $1419-1422$.

Schlag, P., Bockler, R., Meyer, H. \& Belohlavek, D. (1979). In Gastric Cancer, pp. 120-128 [C. H. Herfarth and P. Schlag, editors]. Berlin, Heidelberg: Springer-Verlag.

Shuker, D. E. G., Tannenbaum, S. R. \& Wishnok, J. S. (1981). Journal of Organic Chemistry 46, 2092-2096.

Tuyns, A. (1983). Nutrition and Cancer 4, 198-205.

Weisburger, J. H., Marquardt, H., Hirota, N., Mori, H. \& Williams, G. M. (1980). Journal of the National Cancer Institute 64, $163-167$. 